\title{
Synthesis of Amine- and Thiol-Modified Nucleoside Phosphoramidites for Site-Specific Introduction of Biophysical Probes into RNA
}

\author{
Shengxi Jin, Chandrasekhar V. Miduturu, David C. McKinney, and Scott K. Silverman*
}

Department of Chemistry, University of Illinois at Urbana-Champaign, 600 South Mathews Avenue, Urbana, Illinois 61801

\section{Table of Contents}

General experimental procedures page S1

${ }^{1} \mathrm{H}$ NMR spectra for $\mathbf{U} 2-\mathbf{U 1 5}$ and ${ }^{31} \mathrm{P}$ NMR spectra for $\mathbf{U 9}$, U10, U14, and U15 pages S2-S19

${ }^{1} \mathrm{H}$ NMR spectra for A2-A15 and ${ }^{31} \mathrm{P}$ NMR spectra for A11 and A15 pages S20-S35

${ }^{1} \mathrm{H}$ NMR spectra for $\mathbf{G 2}-\mathbf{G 1 4}$ and ${ }^{31} \mathrm{P}$ NMR spectra for $\mathbf{G 1 1}$ and $\mathbf{G 1 4}$. pages S36-S50 5'- ${ }^{32} \mathrm{P}-$ Radiolabeling of RNA oligonucleotides to demonstrate purity. page S51

General Experimental Procedures. Reagents were commercial grade and used without purification unless otherwise indicated. Dry solvents were obtained from Aldrich Sure/Seal (pyridine, $\mathrm{MeOH}$ ) or Acros Acroseal (DMF, $\mathrm{CH}_{3} \mathrm{CN}$ ) bottles or by passage through activated neutral alumina under positive argon pressure $\left(\mathrm{CH}_{2} \mathrm{Cl}_{2}\right.$, THF). All reactions were performed at room temperature under argon or nitrogen unless otherwise noted. Reaction temperatures of $0{ }^{\circ} \mathrm{C}$ and $-78{ }^{\circ} \mathrm{C}$ were maintained with icewater and dry ice-acetone baths, respectively. Thin-layer chromatography (TLC) was performed on silica gel plates pre-coated with fluorescence indicator with visualization by UV light $(254 \mathrm{~nm})$. Organic solutions that were dried over $\mathrm{Na}_{2} \mathrm{SO}_{4}$ or $\mathrm{MgSO}_{4}$ were filtered through Whatman \#1 or \#4 paper to remove the drying agent, and the paper was rinsed into the collection flask with an appropriate organic solvent. All purifications were by silica gel (230-400 mesh) column chromatography, unless otherwise noted. Note carefully the $\mathrm{Et}_{3} \mathrm{~N}$ treatment of silica gel, because pre-washing silica gel with $\mathrm{Et}_{3} \mathrm{~N}$ changes the elution characteristics of many compounds. NMR spectra were obtained on Varian NMR spectrometers at the indicated frequencies. ${ }^{1} \mathrm{H}$ and ${ }^{13} \mathrm{C}$ chemical shifts in parts per million $(\delta)$ were referenced to internal tetramethylsilane (TMS). The designation “ABq” for a ${ }^{1} \mathrm{H}$ NMR peak indicates that the particular peak was one partner of an $\mathrm{AB}$ quartet; if additional splittings were evident, they are noted following the $\mathrm{ABq}$ designation (e.g., ABqd). In the ${ }^{1} \mathrm{H}$ NMR spectra, peaks not assigned to the indicated compound are labeled as follows: $\mathrm{w}=$ water; $\mathrm{n}=\mathrm{NMR}$ solvent; $\mathrm{t}=$ triethylamine; $\mathrm{s}=$ common solvent (e.g., $\mathrm{CH}_{2} \mathrm{Cl}_{2}$ or EtOAc); $\mathrm{x}=$ unidentified impurity. ${ }^{31} \mathrm{P}$ chemical shifts in $\delta$ were referenced to external $\mathrm{H}_{3} \mathrm{PO}_{4}$ at 0 ppm. ${ }^{19} \mathrm{~F}$ chemical shifts in $\delta$ were referenced to external $1 \%$ $\mathrm{CF}_{3} \mathrm{CO}_{2} \mathrm{D}$ in $\mathrm{D}_{2} \mathrm{O}$ at $-76.53 \mathrm{ppm}$, where $\mathrm{CFCl}_{3}$ is at $0 \mathrm{ppm}$. Mass spectrometry data were obtained at the UIUC School of Chemical Sciences mass spectrometry laboratory using a Micromass ZAB-SE or 70SE-4F instrument (EI), a Micromass Q-Tof Ultima instrument (ESI), or a Voyager SE-DTR instrument (MALDI). 